DOI 10.4467/2543733XSSB.19.005.11404

\title{
PIERWSZE POLSKIE REPORTAŻE Z FRONTÓW WIELKIEJ WOJNY - W „NOWEJ REFORMIE” I ,ILUSTROWANYM TYGODNIKU POLSKIM” (ASPEKT GENOLOGICZNY I HISTORYCZNY)
}

\author{
The First Polish reportages from the Fronts of the Great War - \\ in „Nowa Reforma” (The New Reform magazine) \\ and „Ilustrowany Tygodnik Polski” \\ (The Illustrated Polish Weekly) (Genological and Historical Aspects) \\ Summary
}

The origins of modern Polish reportage is closely related to the outbreak of the Great War (1914-1918). The world's first mass scale armed conflict was also a particular challenge for writers, journalists and artists, who volunteered to fight in the ranks of the legions under the command of Józef Piłsudski. It was there that the following first reportage texts were written: 1/ Pierwsze Bitwy (The First Battles) by Gustaw Daniłowski - documenting the expedition to the Kingdom and the unsuccessful occupation of Kielce, and 2/ the series of Bitwa pod Konarami (The Battle of Konary) by Juliusz Kaden-Bandrowski, describing the first big victories of the legionaries over the Russians alongside the Austrian and Hungarian armies. The genological analysis of these texts and the circumstances in which they were written were presented in view of their role in the idea of independence followed by the periodicals that were issued in Krakow at that time: "Nowa Reforma" (The New Reform) and "Ilustrowany Tygodnik Polski" (The Illustrated Polish Weekly) (the texts were published in both of them).

Keywords: war reportage, Polish reportage, World War I, Polish legions, "Nowa Reforma” (“The New Reform"), "Ilustrowany Tygodnik Polski" ("The Illustrated Polish Weekly"), Gustaw Daniłowski, Juliusz Kaden-Bandrowski

Słowa kluczowe: reportaż wojenny, reportaż polski, I wojna światowa, Legiony polskie, „Nowa Reforma” „Ilustrowany Tygodnik Polski”, Gustaw Daniłowski, Juliusz Kaden-Bandrowski 


\section{Kto byl pierwszy?}

Istnieją dwa teksty pretendujące do miana pierwszego polskiego reportażu dotyczącego I wojny światowej, które jednocześnie można uważać za otwierające nowoczesną historię tego podgatunku (słynne teksty Wańkowicza, dotyczące służby przyszłego pisarza i reportera w korpusie polskim gen. Dowbór-Muśnickiego w Rosji - są późniejsze, w dodatku znacznie mniej reprezentatywne, gdy idzie o typologię gatunku).

Pierwszeństwo w stworzeniu polskiego reportażu dotyczącego Wielkiej Wojny przyznał wiele lat temu Michał Sprusiński - Juliuszowi Kadenowi-Bandrowskiemu (1885-1944). Zrobił to w swej wnikliwej monografii nt. autora Generała Barcza: Juliusz Kaden-Bandrowski. Życie i twórczość ${ }^{1}$, dawno, bo w roku 1971. Tekst Kadena-Bandrowskiego, o którym mowa, to Bitwa pod Konarami, opublikowana w 1915 roku w niedużej broszurce ${ }^{2}$, zawierającej obok reportażu tytułowego teksty rozszerzające go o przed- oraz poakcję: Po drodze, Przejście I Brygady przez Nidę, Nabożeństwo po bitwie, Podwieczorek po bitwie, Grób Herwina, Śmierć porucznika Franciszka Grudzińskiego, Jakub Darocha-Mieczysław Kwieciński - Jakub Bagniewski, Rozkaz dzienny brygadiera Pitsudskiego. Spośród tych tekstów na miano reportażu zasługują obok tytułowego - najobszerniejsze i akcyjne - Przejście I Brygady przez Nidę i Po drodze. Właśnie ten ostatni tekst znalazł się wcześniej w numerze „Ilustrowanego Tygodnika Polskiego”, $\mathrm{nr} 1^{3}$, i to on mógłby uchodzić raczej za pierwszy publikowany w prasie wojenny reportaż Kadena. Wkrótce, prawie równolegle, powstał inny jeszcze tekst tego pisarza-legionisty o pierwszych zmaganiach I Brygady: Bitwa pod Łowczówkiem (dotyczący wydarzeń z 22-25 grudnia 1914, zamieszczony w kolejnej książeczce, to jest w pierwszym wydaniu zbioru Pitsudczycy (1915)) ${ }^{4}$, słynnym także z tego, iż to tu, w tekście tytułowym, rozpoczął Kaden budowę legendy Legionów i ich Komendanta, ukuł też słynną do dziś i powszechnie używaną nazwę polskiej formacji - nazwę początkowo ostro krytykowaną, nawet odrzuconą przez wydawcę, jako niestosowną i mało ,rynkową”. Cóż, paradoks. Stworzona przez Kadena nazwa przyjęta została szeroko, przez polityków, publicystów, historyków, jako synonim ludzi legionowych, a potem całego obozu politycznego w dwudziestoleciu. Do miana pierwszego polskiego korespondenta-reportażysty Wielkiej Wojny dodatkowo jeszcze mogą predestynować Kadena teksty z cyklu Portrety I Bryga$d y$, drukowane w „Wiedeńskim Kurierze Polskim” (w numerze 173 z 1915 roku), aczkolwiek z genologicznego punktu widzenia nie są to w żadnym razie reportaże (a raczej ,portrety”, czyli sylwetki), a przecież o pierwszeństwo w tym gatunku tu chodzi.

Niejako w cieniu mistrza, a zarazem - pamiętajmy, jednego z najbardziej cenionych i lubianych przez Komendanta adiutantów i towarzyszy broni, pozostał inny weteran legionowy, postać równie bliska Piłsudskiemu i oddana idei niepodległościowej, a mianowicie Gustaw Daniłowski (1872-1927). To właśnie on, zapomniany dziś pisarz modernista, opublikował na pierwszej stronie krakowsko-galicyjskiego dziennika „Nowa Reforma”, 28 sierpnia 1914 roku, tekst pod znamiennym tytułem Pierwsze bitwy, dotyczący wyprawy kadrówki z Oleandrów na ziemie Królestwa, wyprawy zakończonej okupacją Kielc.

\footnotetext{
${ }^{1}$ M. Sprusiński, Juliusz Kaden-Bandrowski. Życie i twórczość, Kraków 1971.

${ }^{2}$ J. Kaden-Bandrowski, Bitwa pod Konarami, Oświęcim 1915.

${ }^{3}$ J. Kaden-Bandrowski, Po drodze, „Ilustrowany Tygodnik Polski”, 1915, nr 1.

${ }^{4}$ Pitsudczycy, Oświęcim 1915.
} 
Przywołany tu monografista Michał Sprusiński, owszem, zauważył tekst Daniłowskiego (dostrzegał też chyba pierwszeństwo czasowe Daniłowskiego nad Kadenem), jednak jako pioniera wskazał swego faworyta, używając argumentu z obszaru genologii i typologii gatunku. Stwierdził bowiem:

Nie był Kaden autorem pierwszych artykułów o I Brygadzie - ogłaszał je w „Nowej Reformie" Gustaw Daniłowski. Natomiast spod jego pióra wyszedł pierwszy reportaż wojenny Bitwa pod Łowczówkiem. [...] Bitwa to zwięzła relacja o przebiegu zmagań, relacja, w której przykłady żołnierskiego męstwa są nader starannie podkreślane. Podobnie zwięzłe, nieledwie 'statyczne' mimo większego rozmiaru będzie drugie Kadenowskie sprawozdanie, z bitwy pod Konarami $[\ldots]^{5}$.

Nasuwa się przy okazji pytanie: dlaczego Sprusiński wycofuje się z typowania Bitwy pod Konarami, czy pomija drukowaną wcześniej Po drodze, wybierając Bitwę pod Łowczówkiem (której druk był późniejszy)?

Wiele lat po monografii Sprusińskiego ukazała się druga taka pozycja, Andrzeja Kaliszewskiego Bagnet i pióro ${ }^{6}$. O ile praca Sprusińskiego zogniskowana była na obszernej i znakomitej twórczości beletrystycznej autora Piłsudczyków, o tyle to ta druga monografia poświęcona została wnikliwej analizie samej tylko publicystyki, stąd też bardziej dokładne badania genologiczne i historyczne w niej przeprowadzono, także w odniesieniu do reportażu wojennego. Autor Wojny i pióra, a zarazem piszący te słowa, z pewnym żalem, ale w imię naukowego obiektywizmu, „oddał” palmę pierwszeństwa Daniłowskiemu. Oba bowiem teksty, Kadena jak i Daniłowskiego - Pierwsze bitwy i Bitwa pod Konarami, ewentualnie jeszcze pretendująca do pierwszeństwa Bitwa pod Łowczówkiem - w równym stopniu nie są bynajmniej idealne pod względem dystynktywnych cech gatunku reportażowego, gdy przyjąć dzisiejsze miary, podobnie jak późniejsze utwory Wańkowicza z debiutanckiego tomiku Strzępy epopei (1923). Mamy bowiem - generalnie - do czynienia z początkami nowoczesnego reportażu wojennego w Polsce. Notabene oprócz wymienionych już nazwisk do grona prekursorów zaliczyć należy jeszcze Stefana Żeromskiego, autora Na probostwie w Wyszkowie (publikowanego w 1920 roku). Zupełnym zaś nieporozumieniem jest nazwanie przez Sprusińskiego Pierwszych bitew ,artykułem”, a zaraz obok relacją, to znów tekstów reportażowych Kadena „sprawozdaniem” - świadczy to o nazbyt swobodnym podejściu badacza do kwestii gatunków dziennikarskich, co może być po części uzasadnione jego głównym powołaniem, jakim jest badanie powieści i opowiadań Kadena, co sumiennie czynił.

Historię tego sporu zakończmy więc konkluzją następującą: w świetle badań za pierwszy polski reportaż wojenny z lat 1914-1918 należy uznać Pierwsze bitwy Daniłowskiego i przyznać mu chlubną palmę pierwszeństwa, jednocześnie podkreślając wkład „Nowej Reformy" w promowanie młodego gatunku. Na drugim miejscu umieścić należy, naszym zdaniem, Po drodze oraz ex aequo Bitwę pod Konarami Kadena-Bandrowskiego (wcześniej nieco opublikowane niż inny konkurujący tekst tego samego autora, Bitwa pod Łowczówkiem).

\footnotetext{
${ }^{5}$ M. Sprusiński, op. cit., s. 87.

${ }^{6}$ A. Kaliszewski, Bagnet i pióro. Twórczość publicystyczna Juliusza Kadena-Bandrowskiego, Toruń 2015.
} 


\section{2. „Nowa Reforma” a początek Wielkiej Wojny}

„Nowa Reforma” to informacyjno-polityczny dziennik galicyjski, ukazujący się w Krakowie (1881-1928), najpierw pod nazwą „Reforma”, a związany z obozem demokratyczno-liberalnym ${ }^{7}$. Pierwszym redaktorem naczelnym był Tadeusz Romanowicz, jeden z przywódców w powstaniu styczniowym. Do najbardziej znanych redaktorów i współpracowników pisma należeli Adam Asnyk i Mieczysław Pawlikowski (słynna rodzina mecenasów kultury - Pawlikowscy z Medyki - wspomagała finansowo założenie dziennika). Przed Wielką Wojną, w czasie Wielkiej Wojny i po niej pismem kierował Michał Konopiński. W czasie wojny dziennik związany był z Naczelnym Komitetem Narodowym, który miał znaczący udział w powołaniu Legionów.

Warte krótkiego choćby prześledzenia jest to, jak z dramatyzmu i patosu informacji o potężniejącym nagle światowym konflikcie wyłania się na łamach pisma polski głos, będący odzwierciedleniem narodowych nadziei na niepodległość.

28 lipca (równo miesiąc po zabójstwie arcyksięcia Franciszka Ferdynanda i jego małżonki w Sarajewie) Austro-Węgry wypowiedziały wojnę Serbii. „Nowa Reforma” obwieszcza to w tym samym dniu, wielkimi czcionkami (nr 305). W porannym wydaniu z 29 sierpnia zamieszczono tekst wypowiedzenia wojny oraz patetyczny komentarz, zatytułowany Alea jacta, w którym czytamy m.in.: „Jest wiara, że jesteśmy częścią dobrej sprawy, za którą cesarz Franciszek Józef I miecz podniósł” (nr 306). Niemcy wypowiadają wojnę: 1 sierpnia Rosji, a 3 sierpnia Francji. 4 sierpnia Wielka Brytania wystąpiła z kolei formalnie przeciwko Niemcom, a 6 sierpnia Austro-Węgry przeciwko Rosji. „Nowa Reforma" informuje więc 2 sierpnia o decyzji Niemców (nr 316), 4 sierpnia o zajęciu przez wojska niemieckie Częstochowy (nr 322), 6 sierpnia o zajęciu Kalisza przez Niemców (nr 327), zaś 8 sierpnia o wkroczeniu do Olkusza i Wolbromia wojsk c.-k. (nr 332). Szczególnie ważna dla nas jest data 9 sierpnia i numer 336 „Nowej Reformy” (nadzwyczajne wydanie!), w którym oznajmiono na pierwszej stronie, w małej korespondencji własnej, o wkładzie polskim: Strzelcy polscy zajęli Miechów - taki tytuł nosi ten materiał, autorem jest prawdopodobnie Gustaw Daniłowski, który maszerował już w składzie Kadrówki (słynny marsz na ziemie Królestwa rozpoczął się, jak wiadomo, 6 sierpnia od przemówienia Piłsudskiego w krakowskich Oleandrach). Nieduży tekst zawiera pochwałę bitności Strzelców, krótko opisuje też ucieczkę Rosjan i tworzenie się milicji obywatelskiej (co z punktu widzenia dzisiejszej wiedzy jest propagandową przesada, bowiem tzw. ,,agitacja wojną" bynajmniej nie wciągnęła Królewiaków w orbitę austriacką, nie przekonała do szans na niepodległość).

10 sierpnia „Nowa Reforma” zamieszcza krótką korespondencję z Wiednia (!) o rzekomej pochwale polskich działań w stolicy, oraz, co ważniejsze, powiadamia po południu o decyzji Austriaków, by wydawać polskim ochotnikom (sokoli, strzelcy, drużyny strzeleckie) karabiny (nr 330). 11 sierpnia przynosi w „Nowej Reformie” znów niedużą anonimową informację o zajęciu Kielc, 13 sierpnia - o zajęciu Jędrzejowa.

17 sierpnia ukazuje się (nr 350) artykuł o przełomowym wydarzeniu dla polskiej wizji wojny: formalnym powołaniu Legionów polskich przez Sejmowe Koło Polskie w Krako-

${ }^{7}$ Por. Media. Leksykon PWN, (red.) E. Banaszkiewicz-Zygmunt, Warszawa 2000; hasło: „Nowa Reforma". 
wie oraz utworzeniu NKN (Naczelnego Komitetu Narodowego). Odtąd już codziennie ukazują się w dzienniku wzmianki, notatki i małe artykuliki o rozwijaniu się ruchu legionowego na prowincji, o datkach wnoszonych na ten cel przez społeczeństwo Galicji. 19 sierpnia wykluwa się wątek korespondencko-reporterski, małym co prawda materiałem, ale pod znamiennym tytułem Z obozu Strzelców (nr 353). Z punktu widzenia genologa ciekawy jest podtytuł, wskazujący na gatunek: „sprawozdanie własne "Nowej Reformy”". Prawie pewne, że autorem tekstu, choć nie został on podpisany, był Gustaw Daniłowski. W tymże numerze, obok „sprawozdania” (a naszym zdaniem: minireportażu), wydrukowano patetyczny tekst poetycki Marsz Strzelców autorstwa znanego pisarza, Władysława Orkana. 23 sierpnia do tematyki legionowej w „Nowej Reformie” włącza się poważna publicystyka. W artykule Fazy ideatu polskiego autor podpisany jako K.I. (rozszyfrowujemy go jako Karola Irzykowskiego, wybitnego krytyka, pisarza, publicystę) wyjaśnia strategię, związaną z przystąpieniem do wojny po stronie austro-niemieckiej. Należy podkreślić, ze nigdzie, w żadnym z materiałów „Nowej Reformy” z tego okresu, nie pada jeszcze, w kontekście Legionów i wyprawy do Królestwa, nazwisko komendanta Piłsudskiego $^{8}$.

I tak doszliśmy do kluczowej dla nas daty: 28 sierpnia, kiedy to na pierwszej stronie „Nowej Reformy” zamieszczony zostaje duży (!), podpisany przez autora i nazwany przez redakcję w podtytule „korespondencją własną”, reportaż Pierwsze bitwy Gustawa Daniłowskiego, datowany w Kielcach, 23 sierpnia, w Pałacu Gubernatora, gdzie okupujące Kielce oddziały polskie miały swój sztab.

\section{Pierwsze bitwy}

W tym miejscu należy przedstawić samego reportera, który był postacią tyleż barwną, co znakomicie reprezentującą specyfikę tych wydarzeń.

Gustaw Daniłowski był już około 1900 roku poetą i prozaikiem znanym, wpisującym się dokładnie w stylistyczno-estetyczne kanony Młodej Polski. Sławę przyniosła przyszłemu legioniście skandalizująca (poprzez mariaż erotyzmu i religii), zatrzymana nawet chwilowo przez cenzurę, powieść Maria Magdalena (1912). Odbiegał jednak nieco Daniłowski od panujących wówczas symbolistyczno-dekadenckich mód swymi zainteresowaniami politycznymi, którym dał wyraz w trzech innych utworach prozatorskich, powstałych przed Wielką Wojną, a szczególnie w powieści z kluczem (opartej na wczesnej biografii Józefa Piłsudskiego) pt. Z minionych dni (1902). W politykę włączył się czynnie już w czasach

${ }^{8}$ Władze austro-węgierskie jak i polscy posłowie oraz działacze komitetów narodowych, widzieli w legionach raczej lojalistyczną przybudówkę do c.-k. armii. Austriacy - przede wszystkim dobry materiał propagandowy, w duchu dewizy cesarstwa: Viribus unitis (wspólnymi siłami). Tymczasem Piłsudski już prowadził skryte zrazu działania, mające przekształcać legiony pod jego dowództwem w niezależne polskie wojsko. W tym celu zorganizował (na papierze) fikcyjny Rząd Narodowy, powstały rzekomo w Warszawie 3 sierpnia, który powołał go na komendanta wszystkich sił polskich w trzech zaborach; kadrę - w postaci strzelców - już formował. Tymczasem ludność Królestwa była źle lub bardzo źle usposobiona do tej inicjatywy, widząc w niej przede wszystkim nowego, gorszego od Rosji okupanta: Austriaków i Niemców. Por. W. Pobóg-Malinowski: Najnowsza historia polityczna Polski, t. II: 1914-1939, Gdańsk 1990; M. Klimecki, Legiony polskie, [w:] Legenda legionów, praca zbiorowa, Warszawa 2010; H. Zieliński, Historia Polski 1914-1918, Wrocław-Warszawa-Kraków-Gdańsk-Lódź 1985. 
studiów. Od 1895 należał do PPS, brał udział w rewolucji 1905 roku, w 1906 roku był więziony na Pawiaku (literackim pokłosiem tego stał się reportaż wspomnieniowy Wrażenia więzienne, 1908). Następnie przeszedł do Frakcji PPS Józefa Piłsudskiego, pomagał w działalności konspiracyjnej. Pracował w Komisji Tymczasowej Skonfederowanych Stronnictw Niepodległościowych. W 1910 roku zaangażował się w działalność Związku Walki Czynnej oraz Strzelca, przechodził strzeleckie szkolenia (w Zakopanem oraz w szkole strzeleckiej w Stróży), zaś w 1913 roku wszedł formalnie w skład jednej z drużyn, mimo iż był już w mocno średnim wieku, w dodatku chorował na gruźlicę. 6 sierpnia Daniłowski wyruszył z krakowskich Oleandrów w pierwszym składzie Kompanii Kadrowej Piłsudskiego. Nie był jedynym intelektualistą-artystą w tym gronie. Wraz z innymi literatami, malarzami, publicystami, uczonymi (m.in. W. Sieroszewski, A. Strug, J. Żuławski, J. Kaden-Bandrowski, L. Gottlieb) tworzył inteligencki trzon „wesołego wojska”, jak mówił o swej pierwszej kompanii Komendant ${ }^{9}$. Ów skład można traktować jako symbol nagłej przemiany, jaka dokonywała się w stłamszonym przez zaborców, a w Galicji uciekającym w sztukę i pozory lojalizmu, narodzie polskim, co pięknie ujął Czesław Miłosz w Traktacie poetyckim następującą strofą:
Dzień ten przygasa. Świece zapalono.
$\mathrm{Na}$ Oleandrach zamek karabinu
Nie szczęka więcej i błonia są puste.
W piechurskich butach odeszli esteci.
Włosy ich zamiótł chłopak u fryzjera.
Stoi na polach mgła i zapach dymu ${ }^{10}$.

$Z$ tego grona wolontariuszy, młodopolskich estetów przemienionych nagle w żołnierzy, wyszli pierwsi żarliwi kronikarze i reporterzy Wielkiej Wojny na ziemiach polskich, z Kadenem-Bandrowskim, Daniłowskim, Strugiem na czele.

Według Grażyny Legutko ${ }^{11}$ Daniłowski nie mógł jednak wymaszerować z Oleandrów w pierwszym rzucie ochotników, ponieważ 6 sierpnia razem z Piłsudskim uczestniczył w Krakowie w posiedzeniu Komisji Skonfederowanych Stronnictw Niepodległościowych (KSSN). Pisarz dołączył jednakże do maszerującej na Kielce Brygady dnia następnego, już w Michałowicach.

Tekst Pierwsze bitwy ma wiele cech dojrzałego reportażu wojennego ${ }^{12}$. Ukazuje obrazowo, akcyjnie, dzień po dniu, nawet godzina po godzinie drogę Kadrówki od granicy w Michałowicach, przez Słomniki, Miechów, Jędrzejów, po pierwsze wkroczenie do Kielc (12 sierpnia). Dalej mowa jest o organizacji nowych władz i obronie miasta przed kilkoma kontratakami rosyjskiej kawalerii oraz Kozaków, chcących odbić utraconą placówkę (co im się zresztą udało). Przykład precyzji przedstawiania czasu i miejsca akcji:

\footnotetext{
${ }^{9}$ Por. W. Jędrzejewicz, Józef Pitsudski (1867-1935). Życiorys, Warszawa 2002.

${ }^{10}$ Cz. Miłosz, Traktat poetycki, cz, I.: Piękne czasy, w: idem, Wiersze, t. 1, Kraków 1984.

${ }^{11}$ G. Legutko, Gustaw Daniłowski - spadkobierca romantycznego słowa i propagator niepodległościowego czynu, [w:] G. Legutko i I. Sadowska, Bojownicy polskiej sprawy. Wackaw Sieroszewski i Gustaw Danitowski wobec myśli i czynu Józefa Pitsudskiego, Kielce 2007.

${ }^{12} \mathrm{Na}$ temat rozwoju i cech reportażu por. m.in. K. Wolny-Zmorzyński, Reportaż-jak go napisać, Warszawa 2003; A. Kaliszewski, Mistrzowie polskiego reportażu wojennego (1914-2014), Kraków 2017.
} 
Siódmy, siódma godzina, siedem minut - zanotowałem w dzienniku z pewnym podniosłym wzruszeniem chwilę, kiedy tajemnie, ale otwarcie, z bronią w ręku przekroczyliśmy w Michałowicach granice Królestwa ${ }^{13}$.

Warto podkreślić widoczne w cytacie odwołanie się narratora do „dziennika”, czyli ujawnienie warsztatu reporterskiego, opartego na sumiennym zbieraniu faktów na bieżąco, w polu, co podkreśla asercję tekstu.

Narrator-autor umieszczony jest bowiem wewnątrz akcji, co czyni reportaż tzw. ,uczestniczącym”, czyli najbardziej pożądanym, wiarygodnym typem podgatunku. Duży walor ma wplatana dokumentacja: wiedza o ruchach własnych i wrogich oddziałów, zamierzeniach taktycznych Polaków, zmieniającej się sytuacji w mieście, stratach osobowych itd. To bardzo przyczynia się do wrażenia pełnej autentyzmu relacji. Np.:

W bitwie, dnia 12 i 13, zginęło 38 ludzi ze strony wroga, my utraciliśmy 10 zabitych i rannych.

Za kwintesencję dobrego klasycznego reportażu wojennego uważa się wszak sceny batalistyczne. Ważnym wyzwaniem dla reportera jest, by tworzyć je jako ekspresyjne i dynamiczne, ale unikać przy tym nadmiernego patosu oraz literackości, zarazem oddając dumę, heroizm, jak i cierpienie, oddziałując skutecznie na wyobraźnię czytelnika. Analiza pokazuje, iż Daniłowski, posiadał tę umiejętność wyważenia aspektów. Posłużmy się cytatem:

Koło godziny 11 podniósł się gorący dymek - moment ciszy - a potem huk. Raz wraz systematycznie, spokojnie poczęły bić armaty - z początku na naszą szczupłą linię tyralierską, wysuniętą w kierunku wschodu, a gdy została granatami spędzona z pola, armaty zwróciły się ku folwarkowi. [...] Pierwsze strzały padły o sto kroków przed nami, wznosząc olbrzymi słup dymu, wreszcie $\mathrm{z}$ jakimś żelaznym świergotem wpadł granat w sam środek podwórza, roztrzaskał się i rozerwał konia.

Potrafi też Daniłowski łączyć epizody stricte bitewne, jak ten właśnie cytowany, z przedstawianiem taktyki i tłumaczeniem zamiarów dowództwa, co zbliża ujęcie do najbardziej pożądanego - panoramicznego, np.:

Pomimo takiej przewagi wroga [snuje się konnica wroga na wszystkich wzgórzach okalających Kielce], szef sztabu postanowił przyjąć bój, by nie demoralizować przedwczesnym odwrotem młodych żołnierzy i ochrzcić ich ogniem. Całą jego troską stało się utrzymanie linii odwrotu przez Korczówkę ku szosie chęcińskiej i w tym celu wysłał na tę drogę całą rozporządzalną jazdę. Około 9 zjawił się oddział konny Sokoła w sile 46 koni.

Kulminacyjny punkt całej narracji to brawurowe i krwawe starcie ułanów Beliny z Kozakami i mobilnym oddziałem rosyjskich karabinów maszynowych, krótko a dynamicznie przedstawione, także głosami rosyjskich jeńców, którzy opisywali lęki w ich sztabie przed „polską bandą”.

Zauważa się też w reportażu całkiem precyzyjną terminologię wojskowa, np. ,jako ariergarda jeden pluton rozsypany w tyraliery”; „od strony Szydłówka posunął ku nam gęsty oddział tyralierski spieszonej konnicy”; ,ruch okalający” itp.

\footnotetext{
${ }^{13}$ Ten i kolejne cytaty za: „Nowa Reforma” 1914, nr 370 (28 sierpnia), s. 1.
} 
Trudno budować dynamiczną i zarazem plastyczną narrację, jak i opis, bez użycia odpowiednio, funkcjonalnie dobranych i stopniowanych środków artystycznych. Sięga po nie również Daniłowski, co ocenić można z dzisiejszego punktu widzenia różnie. I tak trudno na przykład zarzucić nadmierną estetyzację takiemu opisowi odpoczywających na biwaku żołnierzy: ,z karabinami u boku rozłożyły się na gołej ziemi, jak grupy lawy, uśpione kompanie". Albo taki elegijny rys nastrojów, wzmacniany impresjonistyczną wizją budzącej się przyrody:

W półśnie, w półmarzeniu, patrzyliśmy, jak bledną i gasną kolejno gwiazdy. Wreszcie oblokło się niebo seledynową poświatą, lekkim różem zabarwiły się obłoki i podniósł się różany świt, a wraz z nim podniosła się w piersiach radość marzenia, że oto stoimy z bronią w ręku w obliczu śmiertelnego wroga, by dać mu godną wolnego człowieka odpowiedź [...].

Są wszakże fragmenty, zwłaszcza w końcowej, refleksyjno-podsumowującej części reportażu, nazbyt jeszcze zanurzone w młodopolskiej poetyce, z której wyrósł przecież Daniłowski, a hiperbolizujące, odrealniające w gruncie rzeczy nieudaną wyprawę do Królestwa. Rozumiemy, iż miały one, jak iskra na dynamit, oddziaływać na emocje czytelnika, budzić w nim zapoznaną polską dumę i wzmacniać niepodległościowe nastroje. A więc mowa w końcówce reportażu o tym, że „zabiło żywym tętnem rycerskie serce Polski”, że „dłoń zniewolona stargawszy pęta zbroi się świetnem lśnieniem zwycięskiego miecza, a nasze stopy ozdobione dźwięczącą ostrogą wstępują w bohaterskie przodków strzemię". Brzmi to jak gorzka ironia w konfrontacji z faktami, których Daniłowski nie podaje, a pisze o nich np. po latach uczestnik tych wydarzeń, Bolesław Wieniawa-Długoszowski, wspominając, że legionowa kawaleria szła przeważnie pieszo (3 kompanie I brygady liczyły 350 ludzi i ledwie 12 koni), rumaki dostawała bądź kupowała „po drodze” od tych życzliwszych spośród agitowanych przez Kadrówkę ziemian. Pierwsze ostrogi kupił sobie Wieniawa w jakiejś mijanej aptece od aptekarza, nie były złote, ale... zardzewiałe ${ }^{14}$. Oczywiście Daniłowski, nawet gdyby chciał, nie mógłby tego - wówczas - podać do publicznej wiadomości, na pierwszej stronie dziennika. Nie przepuściłaby tego austriacka cenzura, podobnie jak faktu wydzielenia legionistom najbardziej archaicznych z posiadanych w magazynach karabinów (i tak nie od razu).

Przesłaniem reportażu jest więc - irracjonalna i nieuzasadniona wtedy - wiara w szybkie zwycięstwo polskiej sprawy dzięki męstwu nielicznych żołnierzy Kadrówki oraz ,mistrzostwu sztuki wojennej”, jaką prezentuje Brygadier i jego dowódcy (co też było oceną na wyrost). W tym sensie reportaż stanowi kolejne ogniwo w łańcuchu wielkiej legendy Piłsudskiego, zapoczątkowanej już wspomnianą wyżej powieścią Daniłowskiego. Wracając do treści reportażu: Strzelcy nie utrzymali się w Kielcach długo, wycofali się we wrześniu (na rozkaz austriackiego sztabu) do Galicji, w okolice Nowego Korczyna, jednak końcowe słowa tekstu okazały się prorocze: „Ten pierwszy chrzest [mowa o starciach kieleckich - AK] rozżagwił płomienne serca żołnierzy, a na ustach został jeden wyraz: Naprzód!".

${ }^{14}$ B. Wieniawa-Długoszowski, Wymarsz $i$ inne wspomnienia, zebrał i wstępem poprzedził R. Loth, Warszawa 1992. 


\section{4. „Ilustrowany Tygodnik Polski” i początki twórczości reportażowej Kadena}

Wydawcą „Ilustrowanego Tygodnika Polskiego”, „pisma poświęconego literaturze i sztuce" (jak głosił podtytuł), liczącego - od sierpnia 1915 roku - 21 numerów, był Naczelny Komitet Narodowy, ten sam, który stał za ideą Legionów. Pismo ukazywało się w Krakowie, a jego redaktorami byli Antoni Stanisław Procajłowicz i Lucjan Rydel. W artykule wstępnym do numeru 1. czytamy:

Prawda, że dziś literaturze ani sztuce bardziej niż kiedykolwiek nie wolno być jałową ni błahą, a już najmniej swawolną czy chorobliwą; dostroić się im przystoi do groźnej powagi tych czasów, podnieść się do tragizmu wypadków dziejowych, krzepić serca mdlejące w bólu i zwątpieniu, budzić w nich wiarę, rozjuszać nadzieję, rozpłomieniać miłość Ojczyzny, w jej imię nawoływać do jedności i zgody ludzi, stany, stronnictwa, czcić i sławić męstwo bohaterów, co nadstawiają piersi za najświętszą sprawę, z pochylonem czołem składać wieńce na świeżych mogiłach tych, którzy za nią polegli, a chwalebne ich imiona opromieniać i podawać w niezatartą pamięć pokoleniom jeszcze niezrodzonym - jakaż to rozległa, jak zbożna i obywatelska praca dla polskich pisarzy, dla polskich artystów, w polskiem piśmie.

$[\ldots]$

Do służby obywatelskiej stajemy z piórem w ręku - pamiętni, że za naszych dni, w oczach naszych dokonywa się przewrót dziejowy o przyszłości Narodu polskiego na długo rozstrzygający. Na ten przełom czekały, z nim swoje nadzieje łączyły wszystkie pokolenia od rozbiorów; Mickiewicz wołał: 'O wojnę powszechną za wolność ludów prosimy Cię, Panie'.

Pismo posiadało piękny i bogaty layout, zróżnicowaną czcionkę, liczne ilustracje, winiety. W treści kładło bardzo duży nacisk na tematykę wojenno-legionową. Każdy numer zaczyna się więc od bloku pt. Z albumu legionistów, zawierającego ryciny, fotografie, reprodukcje dzieł sztuki o tematyce narodowej. Częste były w piśmie artykuły rocznicowe, historyczne, także poświęcone polskim zabytkom (pozostającym w trzech zaborach), narodowej sztuce. Obok drukowano bieżącą publicystykę na temat wojny i sprawy polskiej, jak np. teksty W. Sokolnickiego. W środku każdego numeru znajdował się konsekwentnie rozwijany cykl Z opowiadań legionistów. Wspomnienia, prezentujący różne gatunki: wspomnienia, notatki frontowe, listy, poezje, opowiadania (te ostatnie najczęściej - Romana Horoszkiewicza i Stanisława Falkiewicza). Cykl ten atrakcyjnie, także poprzez liczne fotografie, dokumentuje czyn żołnierski, acz nie zawiera dojrzalszych reportaży wojennych czy prereportaży. Wyjątkiem jest właśnie tekst Kadena: Po drodze (nr 1); zaś w numerze 13. wydrukowana została $R d z a$ - opowiadanie wojenne tegoż autora, stanowiące potem część cyklu prozy Kadena, włączonego do tomiku Spotkanie (Kraków 1916). W numerze 19. znajdujemy obrazek reportażowy Mogity, wkrótce będący tytułowym utworem wydanego w tymże 1915 roku przez Kadena (Lublin 1915) zbiorku literackich nekrologów legionistów. W numerze 11. znalazł się kolejny tekst prezentujący ten gatunek publicystyczny: Trzej gospodarze. Litwinowicz, Dąbrowa Młodzianowski, L. Dzieduszycki, a w 14. jeszcze jeden - Mogiła Herwina. Również w „Ilustrowanym Tygodniku Polskim” (nr 5, 6) w tym samym dziale, co wymienione już utwory, drukował Kaden w odcinkach Zapiski porucznika Pększyca-Grudzińskiego ${ }^{15}$ (z pod-

\footnotetext{
${ }^{15}$ Zginął pod Konarami podczas zwiadu, śmiertelnie trafiony w głowę.
} 
tytułem: opracował J. Kaden-Bandrowski) - tekst ten, wydany potem (poszerzony) w formie małej książeczki, może być traktowany jako hybrydyczny reportaż ,z drugiej ręki”.

Unikatowe połączenie walorów autentyku oraz cech niepowtarzalnego artyzmu wynikają z wcześniejszego (przed 1914) doświadczenia pisarskiego, jak i publicystycznego. Kaden wydał w 1911 tom nowel Zawody, będący autentystyczno-dokumentarnym studium pracy i życia prywatnego krakowskich rzemieślników i robotników. Wcześniej, przebywając kilka lat w Belgii (w związku z edukacją muzyczną - miał być wirtuozem fortepianu), pisał stamtąd do pism krakowskich korespondencje, recenzje, szkice, dotyczące głównie sztuki, ale i tematyki społecznej. Działalność publicysty kontynuował po powrocie do Krakowa, przesuwając tematykę w kierunku historyczno-niepodległościowym, co wiązało się też z jego zaangażowaniem w Strzelcu - gdy wybuchła wojna, Kaden należał już do bliskich współpracowników Komendanta, który poznał się na jego talencie publicysty i organizatora. 2 sierpnia, a więc na kilka dni przed wymarszem z Oleandrów, w „Naprzodzie” ukazał się utrzymany w patetycznym stylu prozy poetyckiej (przypominającym Księgi narodu polskiego i pielgrzymstwa polskiego Mickiewicza) apel Kadena, wzywający rodaków „do szeregu” oraz do gotowości poniesienia wszelkich wyrzeczeń w imię wyzwolenia Ojczyzny po 120 ponad latach niewoli, a zatytułowany symbolicznie Godzina. „Rzuć wszystko, co by nie było szczerą prostotą Szeregu. I niech w nim huczy twój śmiech rycerski, i żeśmy rzucili wszystko, by kośćmi wroga grać w kości”"16 - czytamy w apelu, będącym jakby introdukcją do słynnej mowy, wygłoszonej wkrótce przez Piłsudskiego do Kadrówki w Oleandrach. Ów patos mesjańsko-romantyczny w powstających po sierpniu 1914 reportażach wojennych Kadena ma źródła w silnej „literackości” jego pisarstwa, zwanej „kadenizmem”, którego istotą była wyszukana metaforyka, intensyfikacja obrazu, oryginalne koncepty w konstrukcji i poincie, połączenie naturalizmu z ekspresjonizmem, postmłodopolskie upodobanie do symbolu. Nie brak tych komponentów i w reportażach, co przyczyniało się do budowy legionowej legendy. Kaden swymi reportażami, sylwetkami, nekrologami bohaterów nie tylko dokumentował heroizm, ale nadawał czynom wymiar ogólny, historiozoficzny, metafizyczny nawet. Dobrym przykładem na to jest drukowany w „Ilustrowanym Tygodniku Polskim” tekst Po drodze, mogący pretendować do miana „drugiego” (po Pierwszych bitwach Daniłowskiego) reportażu wojennego.

\section{Po drodze i Bitwa pod Konarami}

Po planowej ewakuacji z Kielc i wycofaniu się z ziem Królestwa, w którym nie udało się Strzelcom wywołać powstania, Piłsudski (listopad 1914) wkroczył ze swymi żołnierzami do Krakowa, prowadząc także grupę jeńców rosyjskich. Został przywitany owacyjnie, zdobył też pochwały od władz austriackich, które doceniły wymiar propagandowy nieudanej wyprawy. Wkrótce odszedł na Podhale, a następnie pod Tarnów. Tam na odcinku frontu pod wsią Łowczówek, w Boże Narodzenie, Strzelcy stoczyli bitwę z przeważającymi siłami rosyjskimi, zakończoną zwycięstwem, acz okupionym stratą 128 żołnierzy oraz ranami wielu innych (22-25 grudnia 1914). Po tej walce Strzelcy zostali skierowani na odpoczynek i reorganizację do Kęt. Tam też otrzymali od dowództwa status I Brygady

\footnotetext{
${ }^{16}$ J. Kaden-Bandrowski, Spotkanie, Kraków 1916, s. 5.
} 
legionowej (z Piłsudskim jako dowódcą). Co do dalszych losów Strzelców i ich Komendanta, zacytujmy historyka, Władysława Pobóg-Malinowskiego:

Pierwsza Brygada Piłsudskiego po odpoczynku i reorganizacji w Kętach - 3 marca 1915 zajęła stanowiska nad Nidą i do początków maja brała udział w toczących się tu walkach pozycyjnych. W ramach ogólnej wielkiej ofensywy od 11 maja Pierwsza Brygada - rzucana na odcinki najgorętsze - biła się pod Konarami, Ożarowem, Urzędowem, Jastkowem, wyróżniając się - jak zawsze - odwagą i żelazną odpornością na najcięższe moralne i fizyczne warunki boju, zdobywając coraz większe uznanie, ale też znacząc ten swój wojenny szlak krwią obficie przelaną i stratą wielu znakomitych oficerów ${ }^{17}$.

Bitwa pod Konarami to druga - po Łowczówku - tak spora i krwawa batalia piłsudczyków (16-17 maja 1915). Legioniści atakowali nawet na bagnety, przy dość ostrożnej postawie innych c.k. formacji sojuszniczych: austriackich, czeskich oraz węgierskich, które nie dotrzymywały Polakom pola ${ }^{18}$. To po Konarach zaczęła się kształtować legenda wielkiego ducha bojowego Brygady i zdolności dowódczych jej Komendanta (tę legendę bardzo wzmacniały właśnie reportaże Kadena).

Drukowany w „ITP” reportaż Po drodze ukazuje wydarzenia usytuowane chronologicznie przed samą bitwą. Opisane są jako marsz ku spodziewanemu zwycięstwu. O tym zwycięstwie zdają się przekonywać narratora (jak i żołnierzy) obiektywne racje, ale przede wszystkim nadzieje, irracjonalnie (wtedy) wpajane przez Piłsudskiego. „Idziemy, jak najświeższych, najprostszych kwiatów ziemi powstanie" (zwróćmy uwagę na znakomicie zasygnalizowany homonim ,powstanie”).

Oryginalny koncept fabuły - służący takiemu przesłaniu - to kontaminacja obrazów idyllicznej i jakby solidaryzującej się z polską sprawą przyrody ze skarbami tradycji materialnej i duchowej Polaków. Gdy legioniści maszerują ku bitwie, to idą krzepiącym ich szlakiem dworów i dworków szlacheckich oraz skromnych wiejskich siedzib. Otwierają się przed nimi w zdecydowanej większości przyjazne i gościnne podwoje, przypominając dumną i piękną kulturę Pierwszej Rzeczypospolitej. Dwory są „teatrum świetności i dumy”, ale też wytęsknionym miejscem odpoczynku po znojnym całodziennym marszu; służą im ciepłą strawą:

Rezydentka czy właścicielka tu, czy tylko sługa... Przez łzy zaprasza na poczęstunek, pół płacze, pół śmieje się, błogosławi, ubolewa i zachęca... [...] Ta sama, co wczoraj i kilkadziesiąt lat temu, dama siwowłosa, pytała każdego z nas o nazwisko ${ }^{19}$ [s. 20-21].

Reporter wprowadził postać na poły fikcyjną, na poły autentyczną, nawiązującą wyraźnie do toposów matki-Polki i powstańczej wdowy czy narzeczonej, znanych z wielu rycin i obrazów (m.in. Malczewskiego) oraz z literatury (powieści Orzeszkowej i Żeromskiego) - cichych strażniczek narodowej sprawy, opiekunek rannych żołnierzy.

${ }^{17}$ W. Pobóg-Malinowski, Najnowsza historia polityczna Polski, t. II: 1914-1939, s. 43-44.

${ }^{18} \mathrm{~F}$. Sławoj-Składkowski, jeden z uczestników bitwy, pisał nawet potem o „zdradzie” sojuszników, sprytnie chowających się za Polaków (S. F. Składkowski, Moja służba w Brygadzie. Pamiętnik polowy, Warszawa 1990 [pierwodr. 1932-1933], s. 57 i n.).

19 „Ilustrowany Tygodnik Polski” 1915, nr 1. Ten i kolejne cytaty za wersją książkową: Bitwa pod Konarami, Oświęcim 1915. 
Mimo iż w reportażu nie brak tak ważnej dla tego gatunku dbałości o topografię, pojawiają się nazwy miejscowości (Śladków, Pińczów, Sieczków), krótkie realistyczne opisy - szczególnie patetycznie i poetycko wystylizowana została kluczowa scenka z Brygadierem Piłsudskim, zasiadającym na sali recepcyjnej jednego z dworów w wielkim starym karle, niczym dawny polski hetman, który nagle ożył, i odbierającym przemarsz radosnej kolumny swoich żołnierzy:

Na sali recepcyjnej we wielkim karle siedzi Brygadier Piłsudski, rzekłbyś - dawny, surowy wielmoża czy generał mohortowskich czasów. Przed nim za balaskami pałacu w złocie powietrza i w czarach wiosennej zieleni mija niebieska kolumna i śpiew:

Jeszcze Polska nie zginęła...

A potem: - Niech żyje Piłsudski (s. 19).

Na koncept kompozycyjny - nawiedzania dworów i dworków - nakłada się dodatkowo dynamizujący narrację refren: „Idziemy, idziemy”. Uderza też subtelnie zaznaczona symbolika, lekka stylizacja (archaizacja staropolska) języka, pięknie wystudiowane obrazy, a także powtarzająca się kilkakrotnie wieloznaczna apostrofa: „Owocu, słodki, owocu życia!” z wariantem: „Synu jedyny, owocu! Słodki owocu życia” - wprowadzająca ton konfesyjno-eschatologiczny, zapowiedź nadciągającej walki na śmierć i życie. Walkę tę zapowiadająjuż odgłosy armat w oddali, które nie sąjednak w stanie zburzyć archetypicznej atmosfery dworu (jak z Pana Tadeusza):

Bateria biła tuż za oknem, a pani czarno ubrana wybierała łyżką masło na liść zielony dla uciekających dzieci (s. 23)

- pojawia się tu rzetelna obserwacja.

W Bitwie pod Konarami autor pokazał przebieg bitwy w sposób bardzo zwięzły, akcyjny, w porządku chronologicznym, przechodząc z czytelnikiem wszystkie jej etapy, stosując całą gamę środków ekspresji, ale i dbając o nazwiska, dane liczbowe, także topografię i przyrodę będącą niemym świadkiem wydarzeń; w sposób naturalny i bardzo funkcjonalny zarazem usytuował Kaden obserwatora-narratora (czyli siebie): jako członek sztabu śledzi on wydarzenia ze wzgórza, obejmując tym samym cały teatr wojenny, mając też wgląd w proces decyzyjny, kształtowanie taktyki, streszczając nawet przychodzące (z góry) dyrektywy i (z dołu) raporty. Zwraca osobną uwagę fakt, iż patrole, ostrzały, starcia z wrogiem nazywa reporter ,pracą”, ,robotą gwałtowną i stanowczą” - podkreśla tym samym profesjonalizm i skuteczność polskich formacji. Czasem relacja przypomina lakonicznością sztabowy raport, np.:

23 maja bataliony nasze, prócz VI-go pod kapitanem Fleszarem, sprzęgły się znów w jedna linię, zajmując samodzielny odcinek frontu, mniej więcej od Kozinka aż do wsi Kujawy. Jądro walki przeniosło się z powrotem na Przepiórków i Kamieniec. Koło południa przyszedł rozkaz ataku, w którym II pułk i I batalion I pułku brały udział aż do 3 godziny rano dnia następnego [s. $\left.41^{20}\right]$.

${ }^{20}$ Lokalizację tego i kolejnych cytatów z reportażu podajemy w nawiasach, za wydaniem: J. Kaden-Bandrowski, Bitwa pod Konarami, Oświęcim 1915. 
Pierwsze wydanie Bitwy pod Konarami ozdobione zostało cyklem fotografii i sztychów, układających się w równoległy fotoreportaż z frontu, a przedstawiających okopy, tabory, patrole legionowe i inne realia dnia codziennego bitwy oraz ówczesnej techniki i taktyki wojny. Jest to więc bardzo dobry, wczesny przykład intergatunkowości w mediach.

Poetyzacje oraz intensyfikacje pojawiają się, by nadać obrazom czynów legionistów wymiar odpowiednio heroiczny i patetyczny bądź wpisać w polskie rycerskie tradycje:

Batalion drugi zapadł się w ziemię i gdy tamten był mieczem ataku, ten został jego tarczą, trzymając się dzielnie pod wściekłym ogniem artylerii [s. 30].

Dokoła wznosiły się olbrzymie czarne słupy dymu płonących wsi i niby złote miecze tnące w jedno miejsce, splątane gęstwy jasnych płomieni [s. 32].

Po obu stronach tego miejsca w ciagu następnych dni przeginały się krwawiące skrzydła bitwy, samo zaś ono stało się jednym wielkim grobem, nad którym krakały wrony i pryskał grad żelaza [s. 33].

Zakończenie Bitwy pod Konarami to błyskotliwa metafora obudzonej siły narodu (drzewa Sławy), wysnuta z zauważonej przez autora homonimiczności: konary jako morfologiczna część drzewa oraz Konary jako nazwa własna - miejscowość, gdzie toczyła się bitwa:

Konary sławne będą w dziejach I Brygady. Tu w młodem ciele ziemi kochanej oddanem, głębokie utkwiły korzenie... Na Konarach Sława kwitnie we krwi, póki czas nie stanie, że z Konarów pędem bujnych gałęzi tryśnie życie i pokój jego szczęśliwy [s. 43].

\section{Zakończenie}

Gustaw Daniłowski musiał niestety - ze względu na pogarszający się stan zdrowia odejść ze służby liniowej już we wrześniu 1914, czyli właściwie tuż po napisaniu reportażu Pierwsze bitwy. Działał jednak nadal aktywnie jako polityk, agitator i właśnie publicysta. Jego reportaże i artykuły na temat Legionów i czynu niepodległościowego znalazły się w tomie Z jednego źródła, wydanym w 1919 roku.

Po odzyskaniu przez Polskę niepodległości Daniłowski pełnił stanowisko urzędnika do specjalnych poruczeń przy Naczelniku Państwa (1918-1925) ${ }^{21}$. Pisarz zmarł 21 października 1927 roku. Józef Piłsudski w dzień po jego śmierci wystosował list kondolencyjny do wdowy, Jadwigi Daniłowskiej, zawierający wymowną charakterystykę przyjaciela i wojennego towarzysza: „Odchodzi od nas bojownik wolności niestrudzony, pisarz, czujący sercem i krwią, żołnierz sprawy ojczystej, człowiek czystości charakteru nieskazitelnej" ${ }^{22}$.

${ }^{21}$ Córka pisarza Elżbieta Daniłowska-Gliwicz była pierwszym oficerem-kobietą służby czynnej w Polsce (w stopniu kapitana), a w 1926 roku Piłsudski mianował ją (w wieku 25 lat) komendantem wojskowej szkoły dla kobiet w Zegrzu.

${ }^{22}$ J. Piłsudski, List do Jadwigi Daniłowskiej (22 października 1927 r.), [w:] idem, Pisma zbiorowe, t. IX, Warszawa 1937, s. 91-92. 
Kaden-Bandrowski stał się czołowym apologetą Piłsudskiego i ,jego” żołnierzy, do których sam należał. Napisał w czasie Wielkiej Wojny, wojny polsko-bolszewickiej, jak i w okresie odzyskanej niepodległości (do 1939) jeszcze dziesiątki tekstów reportażowych, wydał kilkanaście książek publicystycznych, zawierających przebogatą dokumentację czynu legionowego, jak i walk nowo powstałego Wojska Polskiego; utrwalił pamięć o wielu narodowych bohaterach. Sam zmarł od ran odniesionych w czasie powstania warszawskiego. Na barykadzie tegoż powstania zginął drugi z jego synów - pierwszy oddał życie wcześniej jeszcze, walcząc w konspiracji.

\section{Bibliografia}

Daniłowski G., Pierwsze bitwy, „Nowa Reforma” 1914, nr 370 (28 sierpnia).

Daniłowski G., Z jednego źródła, Warszawa 1919.

Jędrzejewicz W., Józef Piłsudski (1867-1935). Życiorys, Warszawa 2002.

Kaden-Bandrowski J., Bitwa pod Konarami, Oświęcim 1915.

Kaden-Bandrowski J., Mogity, Lublin 1915.

Kaden-Bandrowski J., Pitsudczycy, Oświęcim 1915.

Kaden-Bandrowski J., Po drodze, „Ilustrowany Tygodnik Polski” 1915, nr 1.

Kaden-Bandrowski J., Spotkanie, Warszawa 1916.

Kaliszewski A., Bagnet i pióro. Twórczość publicystyczna Juliusza Kadena-Bandrowskiego, Toruń 2015.

Kaliszewski A., Mistrzowie polskiego reportażu wojennego (1914-2014), Kraków 2017.

Klimecki M., Legiony polskie, [w:] Legenda Legionów, praca zbiorowa, Warszawa 2010.

Legutko G., Gustaw Daniłowski - spadkobierca romantycznego słowa i propagator niepodległościowego czynu, [w:] G. Legutko i I. Sadowska, Bojownicy polskiej sprawy. Wackaw Sieroszewski i Gustaw Daniłowski wobec myśli i czynu Józefa Pitsudskiego, Kielce 2007.

Media. Leksykon PWN, (red.) E. Banaszkiewicz-Zygmunt, Warszawa 2000; hasło: „Nowa Reforma".

Miłosz Cz., Traktat poetycki, w: idem, Wiersze, t. 1, Kraków 1984.

Piłsudski J., List do Jadwigi Daniłowskiej (22 października 1927 r.), [w:] idem, Pisma zbiorowe, t. IX, Warszawa 1937.

Pobóg-Malinowski W., Najnowsza historia polityczna Polski, t. II: 1914-1939, Gdańsk 1990.

Składkowski S. F., Moja służba w Brygadzie. Pamiętnik polowy, Warszawa 1990.

Sprusiński M., Juliusz Kaden-Bandrowski. Życie i twórczość, Kraków 1971.

Wieniawa-Długoszowski B., Wymarsz i inne wspomnienia, zebrał i wstępem poprzedził R. Loth, Warszawa 1992.

Wolny-Zmorzyński K., Reportaż - jak go napisać, Warszawa 2003.

Zieliński H., Historia Polski 1914-1918, Wrocław-Warszawa-Kraków-Gdańsk-Lódź 1985.

Andrzej Kaliszewski - doktor habilitowany w dziedzinie nauk humanistycznych, literaturoznawca, medioznawca, profesor UJ (Instytut Dziennikarstwa, Mediów i Komunikacji Społecznej, Wydział Zarządzania i Komunikacji Społecznej Uniwersytetu Jagiellońskiego).

Opublikował m.in.: Mistrzowie polskiego reportażu wojennego (1914-2014) (Kraków 2017), Bagnet i pióro. Twórczość publicystyczna Juliusza Kadena-Bandrowskiego (Toruń 2015), „, Stowo czynów cieniem". Polski reportaż wojenny i publicystyka wojenna autorów kręgu Legionów Polskich i Korpusów Polskich (1914-1920) (Kraków 2013), Główne nurty w kulturze XX i XXI wieku (War- 
szawa 2012), Gatunki dziennikarskie. Teoria - praktyka - język (współaut. K. Wolny-Zmorzyński i W. Furman; Wydawnictwa Akademickie i Profesjonalne 2006, 2009), Nostalgia stylu. Neoklasycyzm liryki polskiej XX wieku w krytyce, badaniach i poetykach immanentnych (Kraków 2007), Gry Pana Cogito (monografia twórczości Zbigniewa Herberta; Kraków 1982, 1990). Jest również autorem wyboru i opracowania antologii reportażu wojennego: Od Oleandrów po Murmańsk (Kraków 2016).

andrzej.kaliszewski@uj.edu.pl

ORCID ID: 0000-0003-2755-4073 